\title{
Toward a Comprehensive Model on Entrepreneurial Intentions of University Students
}

\author{
Al-Qadasi Nabil \\ School of Management, Jilin University, Changchun, China \\ Email: alnabil1976@gmail.com
}

How to cite this paper: Nabil, Al-Q. (2021) Toward a Comprehensive Model on Entrepreneurial Intentions of University Students. Open Journal of Business and Management, 9, 114-135. https://doi.org/10.4236/ojbm.2021.91007

Received: April 16, 2020

Accepted: December 26, 2020

Published: December 29, 2020

Copyright $\odot 2021$ by author(s) and Scientific Research Publishing Inc. This work is licensed under the Creative Commons Attribution International License (CC BY 4.0).

http://creativecommons.org/licenses/by/4.0/

Open Access

\begin{abstract}
This article aims to explore and empirically test a comprehensive model on entrepreneurial intentions of final year university students in which some personality, environmental and situational factors were included. The questionnaire survey method was applied by a random sample of 487 students from various programmes such as commerce \& economic, sciences, computer \& IT, law, agriculture, medical and engineering studying at two major universities in Yemen. Using a modified version of Davidsson's model as a conceptual framework, this article attempted to integrate three constructs personality traits, instrumental readiness and situational factor to explain the relationship between these antecedents and entrepreneurial intention. The results were based on correlation and regression analysis. The results indicated that personality traits have significant impacts on entrepreneurial intention; instrumental readiness does not have a significant impact and situational factor has a significant impact on entrepreneurial intention. The article also found need for achievement as the most important and significant impact on entrepreneurial intention and prior work experience contributed as the second factor but negatively impacts on entrepreneurial intention. This puts personality traits as the dominant factor of the entrepreneurial intention of university students. This article adds to the existing entrepreneurship literature on factors affecting entrepreneurial activities that the crisis does not motivate university students for entrepreneurial intentions, as well as that it harmed their entrepreneurial intentions. In addition, the article concluded that Davidsson's model could be considered as the primary antecedent of entrepreneurial intentions.
\end{abstract}

\section{Keywords}

Entrepreneurial Intention, Personality Traits, Instrumental Readiness, 
Situational Factor, University Students, Yemen

\section{Introduction}

Across the globe, entrepreneurship has played an important role in economic progress and growth. As one of the basic impulsive forces of economic development, entrepreneurship and small and new firms have contributed significantly by attaining economic growth, high employment, creation of strong job opportunity, positive social change and providing support to domestic economy (Acs et al., 2005; Fayolle et al., 2006; Liñán et al., 2011; Romer, 1994; van Stel et al., 2005; Thurik \& Wennekers, 2004). Fostering entrepreneurial actions among university students has become an important topic for entrepreneurship researchers, as entrepreneurship is considered a key to the ever-growing problem of unemployment among graduates from higher education institutions. Accordingly, developing countries like Yemen encourage its citizens to be involved in entrepreneurial activity and consider entrepreneurship as a viable career choice. Nevertheless, the research on entrepreneurship intentions of university students in Yemen is scarce. Thus, this study aims to cover this shortage by investigating the entrepreneurial intentions of two major higher educational institutions which are Sana'a University (public) and University of Science and Technology (private). By doing so, it implicitly considers the influence of students' entrepreneurial education on shaping their entrepreneurial intentions.

Most prior research of entrepreneurship has focused on demographic, personality and environmental factors in investigating entrepreneurial intentions. In most of those research, the antecedents of entrepreneurial intention were addressed as a separate factors; few studies attempted to test comprehensive models (Davidsson, 1995; Kristiansen \& Indarti, 2004; Lüthje \& Franke, 2003; Sesen, 2013). In this study, we attempt to fill this research gap of entrepreneurship literature through exploring the antecedents of entrepreneurial intentions in a comprehensive model including some personality traits, environmental and situational factors. In this regard, the general objective of this study is to explore the antecedents of entrepreneurial intention in a comprehensive model. The specific objectives are: first, to study the impact of personality traits on entrepreneurial intention; second, to know the influence of environmental factors on entrepreneurial intention; third, to comprehend the impact of the situational factor, crisis effect, on the entrepreneurial decision. With these aims, the remaining of this article is structured as follows. Section one provides a brief review of the relevant literature. Section two highlights the methodology applied in the research. Section three presents the results, followed by a discussion devoted to the results obtained. The last section is conclusions, implications, limitations and future research direction.

The context of the study 
This study was conducted in Yemen, a country that suffered a series of crises since March 2015. The ongoing conflict has imposed grievous costs on the nation, damaging lives, property and essential infrastructure and collapsing the country's already fragile economy. The country had sunk to the bottom of the United Nations Development Programme (UNDP 2019), Human Development Index (HDI) Moyer et al. (2019). Yemen now ranks 177 out of 189 countries on the HDI in comparison to 153 prior to 2015 (Human Development Report, 2019). According to recent figures published by the World Bank in winter 2019, Yemeni GDP contracted by an accumulated 39\% in the period between 2014 and 2019. Furthermore, the crisis has dramatically diminished employment and income opportunities in the private and public sector, that led towards losing many job opportunities and making the unemployment rate doubled from (14.6\%) in the year 2010 .

In Yemen, entrepreneurship and Micro, Small and Medium-size Enterprises (MSMEs) are closely related, where the small and new firms have contributed significantly by new job creation. In that way it helped to address one of the main problems facing young people, especially university graduates and provided support to the local economy. The private sector in Yemen provides many opportunities for self-employment. According to the MSE Baseline Survey of 2000 , the number of SMEs is estimated at 311,000 firms which employ around 500,000 of private-sector-workers, out of which 224,000 are individual firms, constituting (72\%) of the total (MSE Baseline Survey, 2000). In addition to the above, MSEs are the main source of income for (70\%) of MSE entrepreneurs (Aliriani, 2013).

\section{Literature Review and Study Hypotheses}

\subsection{Entrepreneurial Intention Concept}

Entrepreneurial intention is one of the basic concepts in studying entrepreneurship, it's considered synonymous with entrepreneurship. Most of the studies use entrepreneurial intention as a proxy for measuring the level of entrepreneurship activity. Entrepreneurial intention was defined in various ways as the intention of a person to start-up a new business venture in the future (Thompson, 2009), the intention of a person to own a business (Crant, 1996), and the intention of a person to be self-employed (Douglas \& Shepherd, 2002). Entrepreneurial intention has a psychological nature, according to (Ajzen, 1991; Krueger Jr. et al., 2000; Shapero \& Sokol, 1982), the intention has proven as the best predictor of an individuals' planned behavior, especially when the behavior is rare and hard to observe or involves an unpredictable amount of time. The stronger an individuals' intention to engage a given behavior, the more likely to perform this behavior (Liñán \& Santos, 2007; Maresch et al., 2016). In our context, we can define entrepreneurial intention as any person who intends to set-up and manages a new business venture for the main purpose of profit-seeking and growth at some point in the future. 


\subsection{Entrepreneurial Intention Model}

The development of the models that explain the entrepreneurial intention is credited to the eighties and nineties of the last century. Shapero \& Sokol (1982) is one of the earliest scholars who developed a model of the Entrepreneurial Event (EEM). According to EEM model, there are three variables that determine of entrepreneurial intention: perceived desirability (the individual attractiveness of starting a business), perceived feasibility (the confidence a person has in their ability to start a business) and entrepreneur's tendency to act (refers to individual's disposition to act decisively when faced with an opportunity).

Theory of Planned Behavior (TPB), by Ajzen (1991). Ajzen developed a psychological model of "Planned Behavior", he suggests three motivational factors which influence the entrepreneurial intention. These predictors are attitudes towards the behavior (the degree to which an individual has a favorable or unfavorable evaluation or appraisal of the behavior in question), subjective norms (the perceived social pressure to perform or not to perform the behavior) and behavioral control (the perceived easiness or difficulty of performing the behavior). TPB has become during recent years one of the main theoretical models frequently used to explain and predict human behavior.

Around these two complementary models, most works dealing with entrepreneurial intention has been developed. In one hand, the EEM is particularly applied to entrepreneurial behavior, on the other, the TPB is more general and refers to a wide range of behavior. However, both models confirm the importance of a person's behavioral intention as a predictor of a person's real behavior.

Davidsson (1995) developed an economic-psychological model to test factors that affect an individual's intentions to go into business. The model combines economic and psychological variables in a set of general attitudes (desire to change, competitiveness, money orientation, achievement, and autonomy), domain attitudes (payoff, social contribution and know-how), and the current situation. Davidsson finds that attitudes are serving as mediators for the influence of personal background variables. According to (Guerrero et al., 2008) Davidsson's model considers as the last formal accredited entrepreneurial intention model was published in 1995. Moreover, Lüthje \& Franke (2003), later suggest a structural model dedicated to exploring the effect of contextual and personality factors on entrepreneurial orientation. Thus, for the purpose of this study Davidsson's model was used and a number of independent variables suggested by the previous empirical studies explained in the following topics.

\subsection{Factors Associated with Entrepreneurial Intentions}

Previous entrepreneurial intention research has identified three factors dominate on the intention to create a business. The first one is demographic factors which include gender, age, past business, etc. The second, personality factors traits, which include need for achievement, filling of control, self-efficacy, etc. The 
third one is environmental factors such as access to finance, available business information, institutional environment, social networks, etc. Correspondingly, this study makes a significant contribution to literature by adding a situational factor related to the study context. We considered it as one of the situational variables that are expected to affect entrepreneurial intention research, we named it the crisis effect (see Figure 1).

\subsubsection{Personality Traits}

There is a growing body of literature arguing that the entrepreneur personality traits and attitudes play a very relevant role in the decision to start a new business (Boyd \& Vozikis, 1994; Çolakoğlu \& Gözükara, 2016; Kristiansen \& Indarti, 2004; Liñán et al., 2011; Mouselli \& Khalifa, 2017; Sesen, 2013; Gerba, 2012; Zain et al., 2010). The present study focuses on the most commonly used which are: Need for achievement, Locus of control and Self-efficacy.

Need for achievement. One of the most widely used psychological variables in personality traits and entrepreneurship research is the need for achievement, it shows whether an individual is inclined to entrepreneurship or not (McClelland, 1961; Wärneryd, 1988; Davidsson, 1991). It is more associated with performance compared with an individual's internal standards (Davidsson, 1995). According to Need for Achievement Theory by McClelland (1961), individuals with a high need for achievement are having a strong desire to be successful. He also assures the importance of the achievement motivation for economic development. Hansemark (1998), reported that the founders of new firms have a higher level of need for achievement. Someprior research shows a positive relation between need for achievement and entrepreneurial intention (Çolakoğlu \& Gözükara, 2016; Gürol \& Atsan, 2006). However, Sharaf et al. (2018) and Sesen (2013) found different results in studies on university students in Egypt and Turkey; they came to the conclusion that the need for achievement has no significant effect on entrepreneurial intention.

Locus of control. Another personality trait that dominates entrepreneurship research is locus of control-the overall belief in a person's power over the outcomes

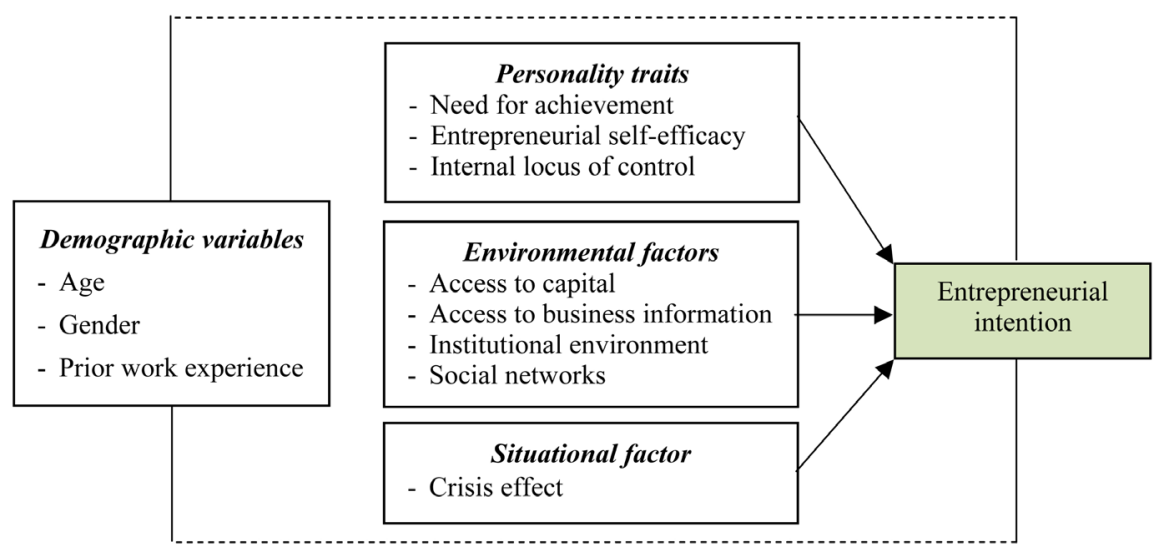

Figure 1. The conceptual model. 
of actions. According to Locus of Control Theory (Rotter, 1966), the individuals more internally oriented are more propensity to believe that reality can be affected by their efforts. In contrast, those who are more externally oriented believe in the power of external conditions. Locus of control considered to be important in individuals' motivation and intentions to start new ventures (Shane et al., 2003). According to (Remeikiene et al., 2013), education mostly contributes to the development of internal locus of control. The results of a number of studies found, that locus of control predicts entrepreneurial intention (Churchill \& Bygrave, 1990; Robinson et al., 1991; Gerba, 2012; Sesen, 2013). However, Kristiansen \& Indarti (2004) and Fayolle et al. (2006) found that the locus of control has no significant effect on entrepreneurial intention.

Self-efficacy. The third personality trait in this study is self-efficacy, which is defined as the degree to which individuals believe they have the ability to successfully start a business (Malebana, 2017). In the field of entrepreneurship, it is related to entrepreneurial intention and termed "entrepreneurial self-efficacy" (ESE). Self-efficacy is a great driver of goal-oriented behavior (Baum \& Locke, 2004; Bandura, 1977). It is the core of the EEM model, the entrepreneurial intention is derived from desirability, feasibility, and propensity to act. Self-efficacy is also in the center of TPB, it represents the perceived behavioral control. The entrepreneurial intention tends to be affected by self-efficacy. Subsequent research has shown that self-efficacy is a significant factor to pursue entrepreneurial intention decision (Zhao et al., 2005; Carr \& Sequeira, 2007; Gerba, 2012; Sesen, 2013).

Within this framework defined by previous literature, we now formulate three research hypotheses to be empirically tested concerning personality traits:

$H 1$ : Need for achievement has a positive impact on entrepreneurial intentions of university students.

H2: Locus of control has a positive impact on entrepreneurial intentions of university students.

$H 3$ : Self-efficacy has a positive impact on entrepreneurial intentions of university students.

\subsubsection{Environmental Factors}

In addition to personality traits, other factors associated with environmental can be important sources of entrepreneurial intentions. Environmental factors are often viewed as filling the gap in the relation between personality traits and entrepreneurial intentions (Lüthje \& Franke, 2003). Previous studies included a large set of environmental factors that might influence the decision to begin an entrepreneurial career (Kristiansen, 2001). In some contributions, access to capital is found to be an important antecedent for the creation of a new venture (Schwarz et al., 2009), availability of information on the potential business sector (Kristiansen \& Indarti, 2004), the social networks (Sequeira et al., 2007), and impact of institutional factors (Mouselli \& Khalifa, 2017). 
Access to capital. One of the issues related to entrepreneurship in general and especially among the youth generation is access to start-ups financing. Several empirical studies have concluded that the lack of start-up capital and the constraints of financial systems considered as the most serious challenge for youth generation to think about launching their own business (Steel, 1994; Meier \& Pilgrim, 1994; Greene, 2005; Cetindamar et al., 2012; Jemal, 2017).

Access to business information. The availability of information on the business environment e.g., markets, sources of inputs, technological solutions, government regulations and rules and how to run a business. According to (Kristiansen \& Indarti, 2004; Minniti \& Bygrave, 1999) access to information is an important element for the intention to launch new ventures. In their study conducted in India Singh \& Krishna (1994), found that information-seeking is the main characteristic of entrepreneurial.

Institutional environment. Institutional environment plays a powerful role in creating or even destroying entrepreneurship in a country (Aldrich \& Wiedenmayer, 1993). The rate of launch new ventures is directly affected by easily or difficulty of establishing businesses in terms of procedures and requirements to obtain a license, where it can influence pursue the entrepreneurial activity. According to (Stephen et al., 2005) environmental formal variables such as legal rules and government support procedures are critical to launching new ventures.

Social networks. Social networks can be defined as a variety of channels, such as family, relatives, friends, or social groups in general. Social networks are important to establish an entrepreneurial venture. It is a way for entrepreneurs to receive information and support. The particular social networks provide information, other immaterial supports and financial support for new entrepreneurs (Butler \& Hansen, 1991). The relatives and friends are not only a source of information and advice but also a source of start-up capital (Aldrich \& Zimmer, 1986). According to (Kristiansen \& Indarti, 2004; Carr \& Sequeira, 2007; Xie \& Lv, 2016; Farooq et al., 2018), social networks may be seen to have strong and positive impacts on a person's intention to be an entrepreneur.

Finally, in this part, the major environmental variable used in this study is "Instrumental Readiness". The coefficient was measured by indicators comprised capital access, business information access, institutional environment and social networks (Kristiansen \& Indarti, 2004; Gerba, 2012; Mat et al., 2015; Gerba, 2012; Memon et al., 2019; Ramayah \& Harun, 2005), and the following hypothesis has been developed:

H4: Instrumental readiness has a positive impact on entrepreneurial intentions of university students.

\subsubsection{Situational Factor}

It is a country-level factor related to the current situation in the study context, specifically the influence of the current status or crisis effect. It's considered one of the situational variables that expected to affect the entrepreneurial decision (Davidsson, 1995; Kennedy et al., 2003; Arrighetti et al., 2016). According to 
some literature, the decision to launch a new business is not independent of the social, political and economic environment conditions where the new business will be operating (Tim et al., 1999; Boyd \& Vozikis, 1994; Lüthje \& Franke, 2003; Turker \& Selcuk, 2009; Virick et al., 2015).

In times of crisis, the features of the economic environment get worse. As a result, we should expect a negative effect on the actual rate of new business creation Klapper \& Love (2011), thus, the current crisis is expected to have a negative impact on entrepreneurial intention. The reason is due to the financial, economic, political, social even psychological constraints imposed by the crisis as well as the shrinking of business opportunities. In contrast, entrepreneurship may push some individuals to become necessity-based-entrepreneurs where the wage employment opportunities are limited. The downside can be that the sustainability of the entrepreneurial enterprise will then be low cause there will be many necessity-based rather than opportunity-based-entrepreneurs. In developing countries, many nascent entrepreneurs engaged in entrepreneurial activities driven by necessity (Kennedy et al., 2003; Cañares, 2011; Devece et al., 2016; Arrighetti et al., 2016). According to (Mouselli \& Khalifa, 2017) crisis might motivate individuals to defend their financial status through supporting their entrepreneurial orientation. In contrast, the crisis might limit the financial resources available and damage individuals' psychological, social and mental conditions. Also, this variable has yet to be thoroughly examined in the entrepreneurial intention literature. This study wishes to make a contribution with respect to the above literature and investigate the effect of the current crisis on entrepreneurial intentions, Yemen context. Thus, we hypothesize:

H5: The current crisis has a negative impact on entrepreneurial intentions of university students.

\section{Methodology}

\subsection{Research Design}

In this study, we intend to analyze the impact of personality traits, instrumental readiness and situational factor on entrepreneurial intentions only from final year university students who are considered one step before entering into self-employment. Entrepreneurial Intention Questionnaire (EIQ) survey method was applied through following various entrepreneurial intention questionnaires which are already tested by previous authors such as (Kristiansen \& Indarti, 2004; Liñán \& Chen, 2009; Sesen, 2013; Mueller \& Thomas, 2001; Mouselli \& Khalifa, 2017). EIQ consists of two parts. The first part represents the demographic data that are usually associated with entrepreneurial intention including (age, gender and prior work experience). The second part of EIQ contains the scales and items that targeting the purpose of the study. All EIQ items are measured using a five-point Likert scale from $1=$ "strongly disagree" to 5 = "strongly agree”. EIQ was translated into Arabic language as an official language in study context by one of the authors. EIQ was administered during class sessions. De- 
pending on the research objectives, data were analyzed by means of the SPSS using descriptive statistics, Pearson correlation and hierarchical multiple regression analysis.

\subsection{Measures}

Measure of personality traits. Based on the previous research (Kristiansen \& Indarti, 2004; Mueller \& Thomas, 2001; Sesen, 2013; Mouselli \& Khalifa, 2017), personality traits and attitudes factors are captured by three scales, need for achievement (four items), internal locus of control (six items) and self-efficacy (four items). Need for achievement is measured by asking participants students to rate themselves to what extent their performances will be better than the previous one's own and better than anybody, e.g. "I will do very well in fairly difficult tasks relating to my study and my work". Internal locus of control is measured by asking participants students to indicate how much feels he/she control over his/her life, e.g. "Diligence and hard work usually lead to success". The third scale was self-efficacy, which is measured by asking students to indicate whether they believed to have the ability to start a business, e.g. "I have leadership skills that are needed to be an entrepreneur".

Measure of instrumental readiness. Based on prior research (Kristiansen \& Indarti, 2004; Ramayah \& Harun, 2005; Gerba, 2012; Memon et al., 2019), access to capital was combined with access to business information, institutional environment and social networks as a one-factor namely instrumental readiness factor, with a combined measurable effect on entrepreneurial intention. Instrumental readiness factor measured by asking participants students to indicate the extent to which they consider the environmental factors could be a barrier or supporter to launching their own business. The scale contains (five items); access to capital (one item): "I have access to capital to start to be an entrepreneur". Access to business information (one item): "I have access to supporting information to start to be an entrepreneur". Institutional environment (two items): "I do not find difficulties (bureaucracy) in the procedures of registering and running companies" and "I did not have problems related to essential infrastructure". Social networks (one item): "I have good social networks if I decide to be an entrepreneur".

Measure of current situational factor. Differently from previous research, this scale was not combined with composite scales but it measured separately. Based on Mouselli \& Khalifa (2017), four-items were used to measure the crisis effect on the entrepreneurial intentions of university students. Three of four items were used as indicators to gather information on the financial, psychological and social status that usually correlate with the entrepreneurial intention, e.g. "My financial situation has been affected dramatically by the crisis". One item with negatively worded was used as indicators to measure to what extent the current crisis limited the necessary resources to start up a new venture "Crisis restricts resources that are necessary to start up business". 
Measure of entrepreneurial intentions. Entrepreneurial intention in this study is a dependent variable measured based on the previous research (Liñán \& Chen, 2009) using (four items), by asking participants students to indicate the extent he/she intends to set-up and manages a new business in the future, e.g. "I am ready to do anything to be an entrepreneur".

Control variables. Previous studies have shown a number of demographic variables which are usually significantly associated with entrepreneurial intentions (Malebana \& Swanepoel, 2015; Mwiya et al., 2017; Sesen, 2013; Potishuk \& Kratzer, 2017). Accordingly, age, gender and prior work experience were used in this study as control variables.

\subsection{Participant}

The participants in the current study consisted of 487 final year university students (71.66 males and 28.33 females) who were actively enrolling in 2019/2020 academic session at Sana'a University (74.53\%), and University of Science and Technology, Yemen. The participants' students were from various programmes such as commerce \& economic, sciences, computer \& IT, law, agriculture, medical sciences, engineering and art. The age distribution of the sample ranged from 22 to 27 years of age, with the average age being $24.11(\mathrm{SD}=1.20)$ years. In total, $89.1 \%$ of the respondents have no prior work experience, whereas $10.9 \%$ of them have in Table 1.

\section{Results}

\subsection{Confirmatory Factor Analysis and Reliability Calculation}

In this study, confirmatory factor analysis (CFA) was used to ensure the construct validity of the study variables through AMOS software, maximum likelihood estimation on the covariance matrix. A model in which all variables were loaded onto separate latent factors was tested. As can be seen from Table 2 the

Table 1. Demographic profile.

\begin{tabular}{ccc}
\hline Category & Frequency & Percent \\
\hline Age & 181 & 37.2 \\
Less than 24 & 232 & 47.6 \\
$24-25$ & 74 & 15.2 \\
More than 25 & & \\
Gender & 349 & 71.7 \\
Male & 138 & 28.3 \\
Female & & 89.1 \\
Prior work experience & 434 & 10.9 \\
Freshman & 53 & \\
Work experience &
\end{tabular}


Table 2. Model fit.

\begin{tabular}{ccccc}
\hline & CMIN/df & GFI & CFI & RMSEA \\
\hline Model fit indicators & 2.458 & 0.900 & 0.937 & 0.055 \\
Suggested values & $<3$ & $\geq 0.90$ & $\geq 0.90$ & $\leq 0.08$
\end{tabular}

Notes: CMIN- $x^{2} ; \mathrm{df}-$ degree of freedom; GFI-goodness-of-fit index; CFI-comparative fit index; RMSEA-root mean square error of approximation.

goodness-of-fit reach the globally acceptable level $(\mathrm{CMIN} / \mathrm{df}=2.458$; GFI $=$ 0.900 ; CFI $=0.937$; RMSEA $=0.055$ ).

To test the reliability of the measuring instrument was done by means of Cronbach's $\alpha$-coefficient. The Cronbach's $\alpha$ scores were ranged from 0.818 for crisis effect to 0.866 for instrumental readiness. Overall, the reliability of the measuring instrument was supported and the questionnaire was considered reliable.

\subsection{Correlation among Entrepreneurial Intention and Study Variables}

The correlation matrix between study variables is shown in Table 3 . The results revealed a positive relationship between entrepreneurial intention and all other variables. The large relationship of entrepreneurial intention was with need for achievement $(r=0.533, p<0.01)$, the medium relationship of entrepreneurial intention was with self-efficacy $(r=0.470, p<0.01)$ and locus of control $(r=$ $0.463, p<0.01)$ while the relationship between entrepreneurial intention and crisis effect $(r=0.133, p<0.01)$, instrumental readiness $(r=0.101, p<0.05)$ was small (Cohen, 1988).

\subsection{The Impact of Study Variables on Entrepreneurial Intention}

Hierarchical multiple regression analysis was used to test study hypotheses and explore whether the independent variables (age, gender, prior work experience, need for achievement, locus of control, self-efficacy, instrumental readiness, crisis effect) had a significant impact on dependent variable (students' entrepreneurial intentions). As shown in Table 4, Model 1 is the base model included only demographic variables (age, gender and prior work experience). Model 2 added personality traits (need for achievement, locus of control and self-efficacy). Model 3 added instrumental readiness. Lastly, in Model 4 crisis effect was entered.

\subsubsection{Demographic Variables}

The regression results in Table 4 show Model 1 with control variables (age, gender and prior work experience) make a combined significant contribution with variance $(14 \%)$ of in entrepreneurial intention. Individually, of the control variables, age was significantly correlated with entrepreneurial intention, prior work experience was also significant but negatively correlated with entrepreneurial intention, while gender was not significantly correlated with entrepreneurial intention. 
Table 3. Mean, standard deviations, Cronbach's a of the variables and correlation matrix.

\begin{tabular}{cccccccccc}
\hline Variable & Mean & SD & Alpha & NA & LC & SE & IR & CE & EI \\
\hline NA & 3.5749 & 0.57290 & 0.850 & 1.00 & & & & & \\
LC & 3.4541 & 0.54091 & 0.843 & $0.645^{* *}$ & 1.00 & & & & \\
SE & 3.2562 & 0.68697 & 0.848 & $0.591^{* *}$ & $0.580^{* *}$ & 1.00 & & & \\
IR & 2.8875 & 0.68995 & 0.866 & $0.173^{* *}$ & $0.185^{* *}$ & $0.260^{* *}$ & 1.00 & & \\
CE & 3.5108 & 0.65852 & 0.818 & 0.038 & -0.015 & -0.079 & -0.065 & 1.00 & \\
EI & 3.7023 & 0.58589 & 0.849 & $0.533^{* *}$ & $0.463^{* *}$ & $0.470^{* *}$ & $0.101^{*}$ & $0.133^{* *}$ & 1.00 \\
\hline
\end{tabular}

Notes: The variables label as follows: NA-need for achievement; LC-locus of control; SE-self-efficacy; IR—instrumental readiness; CE—crisis effect; EI-entrepreneurial intention. Significant at: ${ }^{*} p<0.05$; ${ }^{* *} p<$ $0.01(n=487)$.

Table 4. Hierarchical regression models.

\begin{tabular}{ccccc}
\hline Variable & \multicolumn{4}{c}{$\beta$} \\
\cline { 2 - 4 } & Model 1 & Model 2 & Model 3 & Model 4 \\
\hline Age & $0.223^{* * *}$ & 0.010 & 0.007 & -0.002 \\
Gender & 0.051 & $0.120^{*}$ & $0.130^{*}$ & $0.135^{* * *}$ \\
Prior work experience & $-0.268^{* * *}$ & -0.023 & -0.026 & -0.067 \\
Need for achievement & & $0.334^{* * *}$ & $0.336^{* * *}$ & $0.307^{* * *}$ \\
Locus of control & & $0.138^{* *}$ & $0.141^{* *}$ & $0.140^{* *}$ \\
Self-efficacy & & $0.198^{* * *}$ & $0.211^{* * *}$ & $0.226^{* * *}$ \\
Instrumental readiness & & & -0.060 & -0.055 \\
Crises effect & & & & $0.158^{* * *}$ \\
$\mathrm{~F}$ & $27.295^{* * *}$ & $42.263^{* * *}$ & $36.669^{* * *}$ & $35.390^{* * *}$ \\
$R$ & 0.381 & 0.588 & 0.591 & 0.610 \\
$R^{2}$ & 0.145 & 0.346 & 0.349 & 0.372 \\
$R^{2}$ change & 0.145 & 0.201 & 0.003 & 0.023 \\
$\Delta R^{2}$ & 0.140 & 0.337 & 0.339 & 0.361 \\
\hline
\end{tabular}

Notes: All columns are standardized $\beta$ values. ${ }^{*} p<0.05,{ }^{* *} p<0.01,{ }^{* * *} p<0.001(n=487)$.

\subsubsection{Personality Traits}

From the point of view of the three personality dimensions in Table 4, it can be tested the research hypotheses concerning these traits and explore whether these variables have a significant impact on entrepreneurial intention.

$H 1$ proposed that need for achievement has a positive impact on entrepreneurial intention of university students. As individuals with a high need for achievement such as taking acceptable risks and have strong passions to outcomes of their performance, they may be inclined to have high entrepreneurial intentions. Our results showed that of all three personality traits variables, need for achievement had the strongest impact on the entrepreneurial intentions of university students $(\beta=0.334, p<0.001)$. Thus, $H 1$ was supported. 
$H 2$ proposed that locus of control has a positive impact on entrepreneurial intentions of university students. Since internal locus of control emphasizes the overall belief that events are under the control of an individual's behaviours, individuals with a high internal locus of control will be more inclined to believe that reality can be affected by their efforts. Our results found a significant effect of internal locus of control on entrepreneurial intentions of university students ( $\beta=0.138, p<0.01$ ). Therefore, based on the result, $H 2$ was supported.

$H 3$ proposed that self-efficacy has a positive impact on entrepreneurial intentions of university students. Final year university students with high self-efficacy can plan their own careers, intent and work to pursue their planned careers, thus, they have strong intentions toward entrepreneurship. The results found a significant impact of self-efficacy on entrepreneurial intentions of university students $(\beta=0.198, p<0.001)$. Thus, $H 3$ was supported.

\subsubsection{Instrumental Readiness}

$H 4$ postulates instrumental readiness has a positive impact on entrepreneurial intention of university students. Instrumental readiness plays a critical role in encourage or discourage final year university students to be entrepreneurs. The failure to access to finance prevents many ventures from starting. Availability necessary information about the market, customers, rivalry and suppliers before starting up a new venture could produce an advantage and thus be a prerequisite for potential entrepreneurs. The rates of launch a new venture affected by easily or difficulty of procedures and requirements to obtain a license. Social networks also play important roles to get the necessary resources, thus, it should be positively related to entrepreneurial intentions. However, our results did not support this idea. The impact of instrumental readiness on entrepreneurial intentions was not significant $(\beta=-0.060, p>0.05)$. For this result, $H 4$ was not supported.

\subsubsection{Situational Factor}

$H 5$ postulates that the current crisis has a negative impact on entrepreneurial intentions of university students. During the period of crisis, perceived harder economic status as a barrier to entrepreneurship, the weaker the students' entrepreneurial intentions. The results show a significant impact of the current crisis on the entrepreneurial intentions of university students. This means the crisis does not motivate university students to establish their entrepreneurial intentions, as well as, the crisis harmed their entrepreneurial intentions $(\beta=0.158, p$ $<0.001$ ) according to this result, $H 5$ was supported.

\section{Discussion}

The study provides empirical evidence for the impacts of demographic background, personality traits, instrumental readiness as well as current situation effect on the entrepreneurial intentions within a sample of final year university students in a comprehensive model. The study found that demographic background (age and prior work experience), personality factors (need for achieve- 
ment, locus of control and self-efficacy) and situational factor (crisis effect) have a significant impact on entrepreneurial intentions. However, gender and instrumental readiness was not found to have a significant impact. This study came out with four important implications for entrepreneurial intentions.

First, the factor strongly related to entrepreneurial intention was need for achievement $(\beta=0.334, p<0.001)$, this finding is consistent with prior research (Popescu et al., 2016; Çolakoğlu \& Gözükara, 2016; Mat et al., 2015; Gürol \& Atsan, 2006; Tong et al., 2011; Yukongdi \& Lopa, 2017). Among personality factors, need for achievement seems to distinguish itself more than the others as a measure of intentions. Need for achievement is one important personality trait that affects individuals' actions to entry into entrepreneurship (Fine et al., 2012). The need for achievement, which can be explained as the degree to which individual sets and strives to reach goals and the degree to which an individual works hard and is satisfied with the results of the work, has been consistently and convincingly connected with entrepreneurial intention. The results of this study point the influence of need for achievement on intention is highlighted as a robust antecedent of entrepreneurial intentions. The high need for achievement pushes an individual to seek out an entrepreneurial career in order to accomplish more achievement and satisfaction than could be obtained from other types of careers. According to (Kerr et al., 2018), need for achievement should lead individuals to seek the challenges which match their personality and boost their confidence in the probability of their success, which might lead to an increase in overall society's growth. It entails expectations of doing something better than the one's own previous accomplishments and better than others. Nevertheless, the need for achievement alone is not enough to completely clear why one would choose to undertake an entrepreneurial activity, but, it does seem to be a key component. The results also show that self-efficacy and internal locus of control are important elements to entrepreneurship intention.

Second, our study found that the access capability of entrepreneurial supporting factors instrumental readiness (accessing capital, accessing information, institutional environment and social networks), not significant impact on entrepreneurial intentions $(\beta=-0.060, p>0.05)$. This result is inconsistent with the findings of Kristiansen \& Indarti (2004) and Ramayah \& Harun (2005) who found a positive relation between entrepreneurial intentions and instrumental readiness (accessing capital, information and networks). This difference may be due to the context of the current study. However, our result is compatible with Gerba (2012) study on 156 business and engineering students in Ethiopia, and the result was that the mean score for instrumental readiness (access to capital, access to information and social networks) was much lower than the mean scores for other variables. Also, our results are consistent with the prior study of Susetyo \& Lestari (2014) who found that instrumental readiness (accessing capital, information and networks) was not significant on the entrepreneurial intentions of Indonesian university students. Yukongdi \& Lopa (2017) did a study in- 
cluded respondents from 12 different nationalities in Asia, they found that the environment for starting a business was no significant on entrepreneurial intention. According to entrepreneurship literature, instrumental readiness supports develop of entrepreneurial intentions and impacts nascent entrepreneurs in the form of access to capital, access to business information, institutional environment and quality of social networks. However, our study findings considered instrumental readiness as one of the major obstacles facing final year university students to consider entrepreneurship as a career choice. Another reason for the negative effect of instrumental readiness maybe as this study was conducted in an underdeveloped and unstable context where instrumental readiness is related to the issues such as unavailability of resources, insufficient capital and a general lack of infrastructural support. Therefore, this finding should be investigated with comparative studies in the future.

Third, one of the study goals concerns the impact of the current crisis on entrepreneurial intentions. The results found the current crisis had a significant effect on students' entrepreneurial intentions $(\beta=0.158, p<0.001)$ which means the crisis does not motivate university students to establish their entrepreneurial intentions and it harmed their entrepreneurial intentions. The results show the crisis impact not only on the financial, psychological and social situation for students, but it also weakened dimensions of entrepreneurship, e.g. the intentions and perceived likelihood. Interestingly, this differs from the findings of a study conducted in the Syrian context, and the result was that the crisis effect was insignificant determinant on Syrian students' entrepreneurial intentions (Kristiansen \& Indarti, 2004). However, the effect of the crises on entrepreneurial intentions are very diverse and depends in each case on a set of interacting factors, such as hampers overall economic activity, a decline in economic opportunities, type of crisis as well as the cause emerging from the entrepreneurship literature, is that there is a distinction between necessity- and opportunity-based entrepreneurship, this may explain the distinction between the two cases. However, entrepreneurial literature's lack of research on the emergence of, and challenges to entrepreneurial activities during periods of crisis is a significant lacuna.

Finally, one purpose of this research was to explain the impacts of personality traits, instrumental readiness and current situation on entrepreneurial intentions of university students in a comprehensive model. The results show that the personality traits of students are more effective than instrumental readiness for the entrepreneurial intention in the study context. Although this research has revealed that the situational variable "crisis effect" has a significant impact on entrepreneurial intentions, the strength of this impact is still unclear. One of the most important factors influences entrepreneurial intentions is instrumental readiness, but its impact on students' intentions in this study has been shown to be insignificant. Unless the environmental factors could be proven to be supportive for entrepreneurial intentions, the dominance of personality traits will continue. 


\section{Conclusion}

\subsection{Implications}

The findings of this research can offer several critical implications for entrepreneurship research. First, it affirms that Davidsson's model is a useful tool for measuring the entrepreneurial intentions of university students. Second, the study found need for achievement was an important personality trait and that instrumental readiness does not have a significant impact. Third, this study has uncovered that crisis seems in fact to have a negative impact on entrepreneurial intentions. Forth, one clear conclusion is that we still lack studies on entrepreneurship intentions in times of crisis. In addition to this, the study also concludes that entrepreneurship is a stepwise process that is influenced by demographic variables, personality traits, environmental and situational factors.

\subsection{Limitations and Future Research Directions}

Like all research, this study has limitations that should be addressed in future studies. It is clear that the results of this study are for a specific context. Although it is theoretically possible to extend this study to other contexts, the specific differences between the context of the study and other contexts over the world straiten the generalization of the findings. Thus, a useful extension would be to conduct this study in other environments that suffer from crises and economic and political instability. In communities suffering from war and crises, entrepreneurship may differently be affected by attributes and contexts. Therefore, it is necessary to overcome the constraints of measuring this factor and to find more accurate measurements. The authors hope that this study could provide an important first step to further examine the antecedents of entrepreneurial intentions in a comprehensive model and could promote future studies in this important area. In addition, the investigation of the effect of entrepreneurial education on shaping entrepreneurial intentions of university students is also a gap and an interesting topic that deserves further research in the study context.

\section{Acknowledgements}

Authors are thankful to the administration staff at Sana'a University and University of Science and Technology as well as the respondents who devoted their time generously to fill out the questionnaires. Our appreciation is also extended to the editor and anonymous reviewers of Open Journal of Business and Management. We are also thankful to all those who offered information and advice on the issue of the entrepreneurial intention of university students.

\section{Conflicts of Interest}

The author declares no conflicts of interest regarding the publication of this paper. 


\section{References}

Acs, Z. J., Arenius, P., Hay, M., \& Minniti, M. (2005). Global Entrepreneurship Monitor 2004 Executive Report. Wellesley, MA and London: Babson College and London Business School.

Ajzen, I. (1991). The Theory of Planned Behavior. Organizational Behavior and Human Decision Processes, 50, 179-211. https://doi.org/10.1016/0749-5978(91)90020-T

Aldrich, H. E., \& Wiedenmayer, G. (1993). From Traits to Rates: An Ecological Perspective on Organizational Foundings. Advances in Entrepreneurship, Firm Emergence, and Growth, 1, 145-196.

Aldrich, H., \& Zimmer, C. (1986). Entrepreneurship through Social Networks. In D. Sexton, \& R. Smilor (Eds.), The Art and Science of Entrepreneurship (pp. 3-23). New York: Ballinger.

Aliriani, K. (2013). Role of Small and Medium Enterprises in the Economy: The Case of Yemen. In Yemen: Challenges for the Future, International Conference (pp. 1-28). UK, London. (Online)

Arrighetti, A., Caricati, L., Landini, F., \& Monacelli, N. (2016). Entrepreneurial Intention in the Time of Crisis: A Field Study. International Journal of Entrepreneurial Behavior \& Research, 22, 835-859. https://doi.org/10.1108/IJEBR-12-2015-0326

Bandura, A. (1977). Self-Efficacy: Toward a Unifying Theory of Behavioral Change. Psychological Review, 84, 191. https://doi.org/10.1037/0033-295X.84.2.191

Baum, J. R., \& Locke, E. A. (2004). The Relationship of Entrepreneurial Traits, Skill, and Motivation to Subsequent Venture Growth. Journal of Applied Psychology, 89, 587. https://doi.org/10.1037/0021-9010.89.4.587

Boyd, N. G., \& Vozikis, G. S. (1994). The Influence of Self-Efficacy on the Development of Entrepreneurial Intentions and Actions. Entrepreneurship Theory and Practice, 18, 63-77. https://doi.org/10.1177/104225879401800404

Butler, J. E., \& Hansen, G. S. (1991). Network Evolution, Entrepreneurial Success, and Regional Development. Entrepreneurship \& Regional Development, 3, 1-16. https://doi.org/10.1080/08985629100000001

Cañares, M. P. (2011). In Violence as in Peace: Violent Conflict and Rural Entrepreneurship in the Philippines. Journal of Small Business \& Entrepreneurship, 24, 253-264. https://doi.org/10.1080/08276331.2011.10593537

Carr, J. C., \& Sequeira, J. M. (2007). Prior Family Business Exposure as Intergenerational Influence and Entrepreneurial Intent: A Theory of Planned Behavior Approach. Journal of Business Research, 60, 1090-1098. https://doi.org/10.1016/j.jbusres.2006.12.016

Cetindamar, D., Gupta, V. K., Karadeniz, E. E., \& Egrican, N. (2012). What the Numbers Tell: The Impact of Human, Family and Financial Capital on Women and Men's Entry into Entrepreneurship in Turkey. Entrepreneurship \& Regional Development, 24, 29-51. https://doi.org/10.1080/08985626.2012.637348

Churchill, N. C., \& Bygrave, W. D. (1990). The Entrepreneurship Paradigm (II): Chaos and Catastrophes among Quantum Jumps? Entrepreneurship Theory and Practice, 14, 7-30. https://doi.org/10.1177/104225879001400203

Cohen, J. W. (1988). Statistical Power Analysis for the Behavioral Sciences (2nd ed.). Hillsdale, NJ: Lawrence Erlbaum Associates.

Çolakoğlu, N., \& Gözükara, İ. (2016). A Comparison Study on Personality Traits Based on the Attitudes of University Students toward Entrepreneurship. Procedia-Social and Behavioral Sciences, 229, 133-140. https://doi.org/10.1016/j.sbspro.2016.07.122 
Crant, J. M. (1996). The Proactive Personality Scale as a Predictor of Entrepreneurial Intentions. Journal of Small Business Management, 34, 42-49.

Davidsson, P. (1991). Continued Entrepreneurship: Ability, Need, and Opportunity as Determinants of Small Firm Growth. Journal of Business Venturing, 6, 405-429. https://doi.org/10.1016/0883-9026(91)90028-C

Davidsson, P. (1995). Determinants of Entrepreneurial Intentions. In RENT IX Work (pp. 1-31). Piacenza, Italy.

Devece, C., Peris-Ortiz, M., \& Rueda-Armengot, C. (2016). Entrepreneurship during Economic Crisis: Success Factors and Paths to Failure. Journal of Business Research, 69, 5366-5370. https://doi.org/10.1016/j.jbusres.2016.04.139

Douglas, E. J., \& Shepherd, D. A. (2002). Self-Employment as a Career Choice: Attitudes, Entrepreneurial Intentions, and Utility Maximization. Entrepreneurship Theory and Practice, 26, 81-90. https://doi.org/10.1177/104225870202600305

Farooq, M. S., Salam, M., ur Rehman, S., Fayolle, A., Jaafar, N., \& Ayupp, K. (2018). Impact of Support from Social Network on Entrepreneurial Intention of Fresh Business Graduates. Education+ Training, 60, 335-353.

https://doi.org/10.1108/ET-06-2017-0092

Fayolle, A., Gailly, B., \& Lassas-Clerc, N. (2006). Assessing the Impact of Entrepreneurship Education Programmes: A New Methodology. Journal of European Industrial Training, 30, 701-720. https://doi.org/10.1108/03090590610715022

Fine, S., Meng, H., Feldman, G., \& Nevo, B. (2012). Psychological Predictors of Successful Entrepreneurship in China: An Empirical Study. International Journal of Management, $29,279$.

Gerba, D. T. (2012). Impact of Entrepreneurship Education on Entrepreneurial Intentions of Business and Engineering Students in Ethiopia. African Journal of Economic and Management Studies, 3, 258-277. https://doi.org/10.1108/20400701211265036

Greene, F. J. (2005). Youth Entrepreneurship: Latent Entrepreneurship, Market Failure and Enterprise Support. Coventry: Centre for Small and Medium Sized Enterprises, Warwick Business School.

Guerrero, M., Rialp, J., \& Urbano, D. (2008). The Impact of Desirability and Feasibility on Entrepreneurial Intentions: A Structural Equation Model. International Entrepreneurship and Management Journal, 4, 35-50.

https://doi.org/10.1007/s11365-006-0032-x

Gürol, Y., \& Atsan, N. (2006). Entrepreneurial Characteristics amongst University Students. Education+ Training, 48, 25-38. https://doi.org/10.1108/00400910610645716

Hansemark, O. C. (1998). The Effects of an Entrepreneurship Programme on Need for Achievement and Locus of Control of Reinforcement. International Journal of Entrepreneurial Behavior \& Research, 4, 28-50. https://doi.org/10.1108/13552559810203957

Human Development Report (2019). Inequalities in Human Development in the 21st Century. Briefing Note for Countries on the 2019 Human Development Report-Yemen. http://hdr.undp.org/sites/all/themes/hdr theme/country-notes/YEM.pdf

Jemal, S. (2017). Entrepreneurial Intention among Undergraduate Agricultural Students in Ethiopia: The Case of Jimma University. African Journal of Business Management, 11, 293-303.

Kennedy, J., Drennan, J., Renfrow, P., \& Watson, B. (2003). Situational Factors and Entrepreneurial Intentions. In Proceedings of SEAANZ 2003 Conference 2003 (pp. 1-12). Ballarat, Australia. https://eprints.qut.edu.au/26752/1/c26752.pdf 
Kerr, S. P., Kerr, W. R., \& Xu, T. (2018). Personality Traits of Entrepreneurs: A Review of Recent Literature. Foundations and Trends ${ }^{\oplus}$ in Entrepreneurship, 14, 279-356. https://doi.org/10.1561/0300000080

Klapper, L., \& Love, I. (2011). The Impact of the Financial Crisis on New Firm Registration. Economics Letters, 113, 1-4. https://doi.org/10.1016/j.econlet.2011.05.048

Kristiansen, S. (2001). Promoting African Pioneers in Business: What Makes a Context Conducive to Small-Scale Entrepreneurship? The Journal of Entrepreneurship, 10, 43-69. https://doi.org/10.1177/097135570101000103

Kristiansen, S., \& Indarti, N. (2004). Entrepreneurial Intention among Indonesian and Norwegian Students. Journal of Enterprising Culture, 12, 55-78.

https://doi.org/10.1142/S021849580400004X

Krueger Jr., N. F., Reilly, M. D., \& Carsrud, A. L. (2000). Competing Models of Entrepreneurial Intentions. Journal of Business Venturing, 15, 411-432. https://doi.org/10.1016/S0883-9026(98)00033-0

Liñán, F., \& Chen, Y. W. (2009). Development and Cross-Cultural Application of a Specific Instrument to Measure Entrepreneurial Intentions. Entrepreneurship Theory and Practice, 33, 593-617. https://doi.org/10.1111/j.1540-6520.2009.00318.x

Liñán, F., \& Santos, F. J. (2007). Does Social Capital Affect Entrepreneurial Intentions? International Advances in Economic Research, 13, 443-453. https://doi.org/10.1007/s11294-007-9109-8

Liñán, F., Rodríguez-cohard, J. C., \& Rueda-cantuche, J. M. (2011). Factors Affecting Entrepreneurial Intention Levels: A Role for Education. International Entrepreneurship and Management Journal, 7, 195-218. https://doi.org/10.1007/s11365-010-0154-Z

Lüthje, C., \& Franke, N. (2003). The "Making” of an Entrepreneur: Testing a Model of Entrepreneurial Intent among Engineering Students at MIT. R\&D Management, 33, 135-147. https://doi.org/10.1111/1467-9310.00288

Malebana, M. J. (2017). Knowledge of Entrepreneurial Support and Entrepreneurial Intention in the Rural Provinces of South Africa. Development Southern Africa, 34, 74-89. https://doi.org/10.1080/0376835X.2016.1259990

Malebana, M. J., \& Swanepoel, E. (2015). Graduate Entrepreneurial Intentions in the Rural Provinces of South Africa. Southern African Business Review, 19, 89-111. https://doi.org/10.25159/1998-8125/5835

Maresch, D., Harms, R., Kailer, N., \& Wimmer-Wurm, B. (2016). The Impact of Entrepreneurship Education on the Entrepreneurial Intention of Students in Science and Engineering versus Business Studies University Programs. Technological Forecasting and Social Change, 104, 172-179. https://doi.org/10.1016/j.techfore.2015.11.006

Mat, S. C., Maat, S. M., \& Mohd, N. (2015). A Descriptive Analysis on Entrepreneurial Intention among Engineering Technology Students. Asian Social Science, 11, 286. https://doi.org/10.5539/ass.v11n24p286

McClelland, D. C. (1961). Achieving Society (No. 15). New York: Simon and Schuster. https://doi.org/10.1037/14359-000

Meier, R., \& Pilgrim, M. (1994). Policy-Induced Constraints on Small Enterprise Development in Asian Developing Countries. Small Enterprise Development, 5, 32-38. https://doi.org/10.3362/0957-1329.1994.017

Memon, M., Soomro, B. A., \& Naimatullah, S. (2019). Enablers of Entrepreneurial Self-Efficacy in a Developing Country. Education and Training, 61, 684-699. https://doi.org/10.1108/ET-10-2018-0226 
Minniti, M., \& Bygrave, W. (1999). The Microfoundations of Entrepreneurship. Entrepreneurship Theory and Practice, 23, 41-52. https://doi.org/10.1177/104225879902300403

Mouselli, S., \& Khalifa, B. (2017). Entrepreneurship in Crisis: The Determinants of Syrian Students' Entrepreneurial Intentions. Business, Management and Education, 15, 159-173. https://doi.org/10.3846/bme.2017.386

Moyer, J. D., Bohl, D., Hanna, T., Mapes, B. R., \& Mickey, R. (2019). Assessing the Impact of War on Development in Yemen. Sana'a: United Nations Development Programme (UNDP).

https://www.undp.org/content/dam/yemen/General/Docs/ImpactOfWarOnDevelopme ntInYemen.pdf

MSE Baseline Survey (2000). Social Fund for Development.

Mueller, S. L., \& Thomas, A. S. (2001). Culture and Entrepreneurial Potential: A Nine Country Study of Locus of Control and Innovativeness. Journal of Business Venturing, 16, 51-75. https://doi.org/10.1016/S0883-9026(99)00039-7

Mwiya, B., Wang, Y., Shikaputo, C., Kaulung’ombe, B., \& Kayekesi, M. (2017). Predicting the Entrepreneurial Intentions of University Students: Applying the Theory of Planned Behaviour in Zambia, Africa. Open Journal of Business and Management, 5, 592-610. https://doi.org/10.4236/ojbm.2017.54051

Popescu, C. C., Bostan, I., Robu, I. B., \& Maxim, A. (2016). An Analysis of the Determinants of Entrepreneurial Intentions among Students: A Romanian Case Study. Sustainability, 8, 771. https://doi.org/10.3390/su8080771

Potishuk, V., \& Kratzer, J. (2017). Factors Affecting Entrepreneurial Intentions and Entrepreneurial Attitudes in Higher Education. Journal of Entrepreneurship Education, 20, 25-44.

Ramayah, T., \& Harun, Z. (2005). Entrepreneurial Intention among the Student of Universiti Sains Malaysia (USM). International Journal of Management and Entrepreneurship, 1, 8-20.

Remeikiene, R., Startiene, G., \& Dumciuviene, D. (2013). Explaining Entrepreneurial Intention of University Students: The Role of Entrepreneurial Education. In International Conference (pp. 299-307). Zadar, Croatia.

http://www.toknowpress.net/ISBN/978-961-6914-02-4/papers/ML13-258.pdf

Robinson, B., Stimpson, D. V., Huefner, J. C., \& Hunt, H. K. (1991). An Attitude Approach to the Prediction of Entrepreneurship. Entrepreneurship Theory and Practice, 15, 13-32. https://doi.org/10.1177/104225879101500405

Romer, M. (1994). The Origins of Endogenous Growth. Journal of Economic Perspectives, 8, 3-22. https://doi.org/10.1257/jep.8.1.3

Rotter, J. B. (1966). Generalized Expectancies for Internal versus External Control of Reinforcement. Psychological Monographs: General and Applied, 80, 1-28. https://doi.org/10.1037/h0092976

Schwarz, E. J., Wdowiak, M. A., Almer-Jarz, D. A., \& Breitenecker, R. J. (2009). The Effects of Attitudes and Perceived Environment Conditions on Students' Entrepreneurial Intent. Education+ Training, 51, 272-291. https://doi.org/10.1108/00400910910964566

Sequeira, J., Mueller, S. L., \& McGee, J. E. (2007). The Influence of Social Ties and Self-Efficacy in Forming Entrepreneurial Intentions and Motivating Nascent Behavior. Journal of Developmental Entrepreneurship, 12, 275-293. https://doi.org/10.1142/S108494670700068X

Sesen, H. (2013). Personality or Environment? A Comprehensive Study on the Entrepre- 
neurial Intentions of University Students. Education + Training, 55, 624-640. https://doi.org/10.1108/ET-05-2012-0059

Shane, S., Locke, E. A., \& Collins, C. J. (2003). Entrepreneurial Motivation. Human Resource Management Review, 13, 257-279. https://doi.org/10.1016/S1053-4822(03)00017-2

Shapero, A., \& Sokol, L. (1982). The Social Dimensions of Entrepreneurship. In C. Kent, D. Sexton, \& K. Vesper (Eds.), Encyclopedia of Entrepreneurship (pp. 72-90). Englewood Cliffs, NJ: Prentice-Hall.

Sharaf, A., El-Gharbawy, A., \& Ragheb, M. A. (2018). Factors That Influence Entrepreneurial Intention within University Students in Egypt. Open Access Library Journal, 5, 1-14. https://doi.org/10.4236/oalib.1104881

Singh, A. K., \& Krishna, K. V. S. M. (1994). Agricultural Entrepreneurship: The Concept and Evidence. The Journal of Entrepreneurship, 3, 97-111. https://doi.org/10.1177/097135579400300106

Steel, W. F. (1994). Changing the Institutional and Policy Environment for Small Enterprise Development in Africa. Small Enterprise Development, 5, 4-9. https://doi.org/10.3362/0957-1329.1994.013

Stephen, F. H., Urbano, D., \& van Hemmen, S. (2005). The Impact of Institutions on Entrepreneurial Activity. Managerial and Decision Economics, 26, 413-419. https://doi.org/10.1002/mde.1254

Susetyo, D., \& Lestari, S. (2014). Developing Entrepreneurial Intention Model of University Students: An Empirical Study on University Students in Semarang Indonesia. International Journal of Engineering and Management Sciences, 5, 184-196.

Thompson, E. R. (2009). Individual Entrepreneurial Intent: Construct Clarification and Development of an Internationally Reliable Metric. Entrepreneurship Theory and Practice, 33, 669-694. https://doi.org/10.1111/j.1540-6520.2009.00321.x

Thurik, R., \& Wennekers, S. (2004). Entrepreneurship, Small Business and Economic Growth. Journal of Small Business and Enterprise Development, 11, 140-149. https://doi.org/10.1108/14626000410519173

Tim, M., Thierry, V., Noelle, D., \& Vicki, T. (1999). Factors Influencing Small Business Start-Ups. A Comparison with Previous Research. International Journal of Entrepreneurial Behaviour \& Research, 5, 48-63. https://doi.org/10.1108/13552559910274499

Tong, X. F., Tong, D. Y. K., \& Loy, L. C. (2011). Factors Influencing Entrepreneurial Intention among University Students. International Journal of Social Sciences and Humanity Studies, 3, 487-496.

Turker, D., \& Selcuk, S. S. (2009). Which Factors Affect Entrepreneurial Intention of University Students? Journal of European Industrial Training, 33, 142-159. https://doi.org/10.1108/03090590910939049

van Stel, A., Carree, M., \& Thurik, R. (2005). The Effect of Entrepreneurial Activity on National Economic Growth. Small Business Economics, 24, 311-321. https://doi.org/10.1007/s11187-005-1996-6

Virick, M., Basu, A., \& Rogers, A. (2015). Antecedents of Entrepreneurial Intention among Laid-Off Individuals: A Cognitive Appraisal Approach. Journal of Small Business Management, 53, 450-468. https://doi.org/10.1111/jsbm.12067

Wärneryd, K. E. (1988). The Psychology of Innovative Entrepreneurship. In Handbook of Economic Psychology (pp. 404-447). Dordrecht: Springer. https://doi.org/10.1007/978-94-015-7791-5 11

Xie, X., \& Lv, J. (2016). Social Networks of Female Tech-Entrepreneurs and New Venture 
Performance: The Moderating Effects of Entrepreneurial Alertness and Gender Discrimination. International Entrepreneurship and Management Journal, 12, 963-983. https://doi.org/10.1007/s11365-016-0413-8

Yukongdi, V., \& Lopa, N. Z. (2017). Entrepreneurial Intention: A Study of Individual, Situational and Gender Differences. Journal of Small Business and Enterprise Development, 24, 333-352. https://doi.org/10.1108/JSBED-10-2016-0168

Zain, Z. M., Akram, A. M., \& Ghani, E. K. (2010). Entrepreneurship Intention among Malaysian Business Students. Canadian Social Science, 6, 34-44.

Zhao, H., Seibert, S. E., \& Hills, G. E. (2005). The Mediating Role of Self-Efficacy in the Development of Entrepreneurial Intentions. Journal of Applied Psychology, 90, 1265. https://doi.org/10.1037/0021-9010.90.6.1265 